\title{
Aesthetic Habitus Analysis of PGSD Universitas Ahmad Dahlan's Students on Visual Arts and Skills Learning Process
}

\author{
Probosiwi \\ probosiwi@pgsd.uad.ac.id \\ Universitas Ahmad Dahlan Yogyakarta
}

\begin{abstract}
The research explained about analysis visual arts and skill learning of PGSD UAD's students. Data collection time at even semester, academic year 2017/2018 in class A, B, C, and H. Type research is qualitative research with descriptive data analysis. Author used aesthetic habitus concept to study its learning for getting in-depth analysis. Result showed that students at sixth semester is needed familiarize themselves seeing, observing, and interacting with visual references directly and continuously. It purposed so they can create the artworks which creative ideas. Research's benefit as a reference to improve visual arts and skills learning in the future for students prospective primary school teacher.
\end{abstract}

Keywords: visual arts and skills learning, aesthetic habitus, qualitative research.

\section{Introduction}

Visual arts learning in elementary schools is a form of activity that develops students abilities in creating visual arts that can be captured by senses of touch. In addition, this learning aims to direct students to understand and obtain satisfaction in responding to the artworks created by students themselves and other people's creations. Experience in the work of fine arts is obtained from how to utilize existing materials and use various kinds of tools. The form of art works called into "dwimatra" (two dimensions) and "trimatra" (three dimensions). As a prospective elementary school teacher, even semester academic year 2017/2018 students at the PGSD Department are invited to be able to utilize the available natural resources into interesting and beautiful artworks. This process is called the exploitation of the media's aesthetic properties and potential. Students are also taught to interact with images, objects, and forms that come from visual references or their empirical experience. It aims to be able to produce works of art that are realistic and adapted to the teaching needs of elementary school students later.

The nature of elementary school students is the character of those who learn something through concrete objects. So, as prospective primary school teachers, students must be able to represent ideas into forms that can be seen and touched. Capital in the work of art is to be creative and using the taste. The main key in making beautiful artworks are by paying attention to the basic elements and principles of fine arts. The basic elements of art consist of points, lines, colors, fields, textures, shapes, spaces and dark light. While the basic principles of art consist of harmony, balance, composition, proportion, rhythm, unity, emphasis, and gradation.

Based on the book "Visual and Performing Arts Framework for California Public Schools" listed the art learning standards for elementary school age students as follows.

"The toolkit is but one example of many available self-evaluation and planning processes, each following similar steps. By using it, a district or school site can determine the implementation of an arts level program-foundation, building, or best practices-and identify 
the next steps to be taken. The use of the toolkit's continuum generates conversation, stimulates research, consensus builds, decision making enhances, and supports planning. Each of the ten focus areas and criteria are discussed, issues arise about the elements valued in arts education program for all students. In examining a school or district program, school or district administrators should consider the following areas (identified in the toolkit): (a) standards-based curriculum; (b) instruction and methodology; (c) student assessment; (d) professional development for those implementing the arts education program; (e) qualified teachers, personnel, and administration programs; (f) partnerships and collaborations; (g) budgetary needs; (h) facilities, logistics, and necessary resources; (i) program evaluation; (j) time and timing[1].

Furthermore, the Curriculum Development and Supplemental Materials Commission explained that "they like to talk about what they see in pictures and use glue and scissors with enthusiasm while learning about lines, color, shape, texture, value, and space in the world around them and in works of art[1]. The age of elementary school students learns the basics of art that will be combined with creativity and expertise in composing basic art elements and principles. The character of elementary school students who depend on concrete manifestations must be able to be shown in terms of objects or techniques or the steps in making artworks in sequence. Based on the book "Visual and Performing Arts Framework for California Public Schools", the Curriculum Development and Supplemental Materials Commission, it is written that.

Visual arts students may walk together and observe the repeated patterns made by the leaves on a tree or the bricks on the side of a building. They may also identify lines, colors, shapes and forms, and textures and observe changes in the shadows and in sunlight. And they may begin to talk about perspective, noticing how objects appear to be larger when close and smaller when far away. Students use this visual information to create works of art on paper and in three-dimensional constructions, using geometric shapes and lines that express feelings. Then they advance into analysis as they discover meaning and stories in works of art and see how other artists use the same lines, colors, shapes, and textures as the students did in their own work. Now they have a vocabulary to use as they tell why they like a work of art they are made and learned about a variety of artwork in the world around them[1].

Based on the explanation, information obtained by elementary school students can change their perspective on the object being viewed. They represent meanings and stories in artwork one of them by looking at and observing how artists use elements of art in each of their works. Artists here can be analogous to a teacher who is giving examples or practice making artworks in front of them followed by an explanation of the work steps. To facilitate the reading of the competencies achieved in the learning of art in elementary schools, the following table is explained.

Table I. Key Standards of Arts Learning Content in Elementary Schools

\begin{tabular}{|l|l|l|l|}
\hline \multicolumn{5}{|c|}{ Key Content Standards Kindergarten } \\
\hline Dance & Music & Theatre & Visual Arts \\
\hline (Artistic Perception) & (Artistic Perception) & (Artistic Perception) & (Artistic Perception) \\
Perform basic locomotor skills & Identify and describe & Use the vocabulary of & Identify the elements of \\
(e.g., walk, run, gallop, jump, & basic elements in & theatre, such as actor, & art (line, color, form/ \\
hop, and balance) & music (e.g., high/low, & character, & shape, texture, value, \\
& fast/slow, loud/ soft, & cooperation, setting, & space) in the \\
& beat) & the five senses, and & environment and in \\
& & audience to descrie & works of art, \\
& & theatrical experiences. & emphasizing line, \\
\hline
\end{tabular}




\begin{tabular}{|c|c|c|c|}
\hline & & & color, and shape/ form. \\
\hline $\begin{array}{l}\text { (Artistic Perception) } \\
\text { Understand and respond to a } \\
\text { wide range of opposite (e.g., } \\
\text { high/low, forward/ backward, } \\
\text { wiggle/freeze) }\end{array}$ & $\begin{array}{l}\text { (Creative Expression) } \\
\text { Sing age-appropriate } \\
\text { songs from memory. }\end{array}$ & $\begin{array}{l}\text { (Creative Expression) } \\
\text { Perform group } \\
\text { pantomimes and } \\
\text { improvisation to retell } \\
\text { familiar stories. }\end{array}$ & $\begin{array}{l}\text { (Aesthetic Valuing) } \\
\text { Decribe what is seen } \\
\text { (including both literal } \\
\text { and expressive content) } \\
\text { in selected works of art. }\end{array}$ \\
\hline $\begin{array}{l}\text { (Creative expression) } \\
\text { Create movements that reflect a } \\
\text { variety of personal experiences } \\
\text { (e.g., recall feeling happy, sad, } \\
\text { angry, excited) }\end{array}$ & $\begin{array}{l}\text { (Creative Expression) } \\
\text { Play instruments and } \\
\text { move or verbalize to } \\
\text { demonstrate } \\
\text { awareness or beat, } \\
\text { tempo, dynamics, and } \\
\text { melodic direction. }\end{array}$ & $\begin{array}{l}\text { (Historical and } \\
\text { Cultural Context) } \\
\text { Retell or dramatize } \\
\text { stories, myths, fabels, } \\
\text { and fairy tales from } \\
\text { various cultures and } \\
\text { times. }\end{array}$ & \\
\hline $\begin{array}{l}\text { (Aesthetic Valuing) } \\
\text { Explain basic features that } \\
\text { distuingh one kind of dance } \\
\text { from another (e.g., spees, forcel } \\
\text { energy use, costume, setting, } \\
\text { music) }\end{array}$ & & & \\
\hline
\end{tabular}

Source: Visual and Performing Arts Framework for California Public Schools[1]

Ross (in Pamadhi[2]) said that the distribution of curriculum in accordance with its usefulness is classified as art education in relation to aesthetic education which can be explained as follows: (1) academics curriculum: contains mathematics, measuring space, etc. which are actually purely scientific disciplines ; (2) social curriculum or practical curriculum namely practical curriculum for applied needs (directly in daily life); (3) humanistics curriculum aims to balance academic work for the benefit of people such as religion, art, sports, and so on, so that their position is real as a practice lesson in art work[2]). In line with number 3, the author focuses on practice-based art education aimed at prospective primary school teachers as a provision for their teaching in the future. Students are encouraged to be able to create artwork in a creative, beautiful and interesting way as part of their fine motor development and gross motoric. The learning is of course adjusted to the KI/ KD that is in the upper class and lower class SBDP material.

The 2013 Curriculum contains the substance of education with aspects of competence affective, cognitive, and psychomotor. In this case, students are required to make innovation and develop basic creativity both as expressions of spontaneity and household needs. A sense of guidance is given to the activities of appreciating the work, creator, and background or concept of work. This is included in the common ground in art education, which is a basic understanding of art learning that can be described in this scheme.

Tabel II. Commonground Pendidikan Kesenian[2]

\begin{tabular}{|c|c|}
\hline Education & Arts \\
\hline Creation & Creativity \\
\hline Sense & $\begin{array}{l}\text { Sensitivity, apreciation, } \\
\text { and aesthetic }\end{array}$ \\
\hline Artworks & Skills \\
\hline
\end{tabular}


Furthermore, Pamadhi wrote suggesting that the position of art can be said to be a value system in teaching and learning; method or method of teaching; educational tools, training skills, life skills; and works that can be learned and used to express ideas; practice imagination skills[2]. At the last point, students often experience difficulties in representing imagination into the form of an object. They are like having doubts and stiffness in moving their hands just to stroke a line, carve a brush, even cut paper.

Beauty is something that is "there" by the creator. In this case the skills in making beautiful and interesting artwork. Objectification of beauty is something that students can do in representing ideas. To get this condition, students need to unite themselves with objects, which is to exert all the senses they have to do empirical experiences.

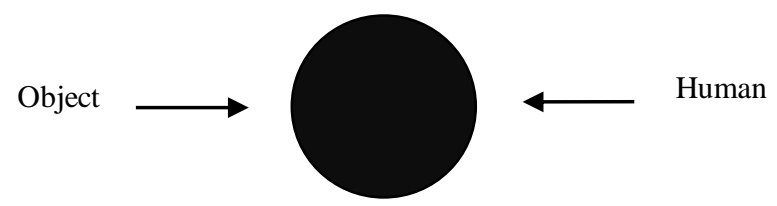

Picture 1. Scheme of Objectification of the Beauty of Subjects in Objects[2]

Based on Figure 1, art education can be an empirical experience and practice sensory observation and be able to observe the environment. In addition, the sense of being becomes the main essence of art and is balanced with expertise to be a set of effective works. Students are directed to hone skills in the area of expertise and skills to be able to produce works of art that are always new.

The behavioral habits of students in honing their abilities are also applied to PGSD UAD's students. This habit is usually called building artistic habitus in everyday life as an example of tidying up tables and chairs in the classroom after completing lectures. Habitus is the process of internalizing the pressure, obstacles, or burdens that happen to someone to the threshold of consciousness (pre-conscious level). Bourdieu (in Grenfell) states that: "habitus as a property of social agents (whether individuals, groups or institutions) that consists of "structured and structuring structures" are structured by one's past and present circumstances, such as family upbringing and education experiences. It is structuring in that one's habitus helps to shape one's present and future practices. It is a "structure" in that it is systematically ordered rather than random or unpatterned. This "structure" comprises a system of dispositions which generate perceptions, appreciations and practices[3].

Art habitus is a psychological awareness of social pressure on a person, group, and even society that is supported by the smallest unit. Pamadhi explained that habitus is a psychological pressure of a person, which leads to natural learning based on its potential[2].

The practice of art work in class A, B, C, and $\mathrm{H}$ of students in the sixth semester of the $2017 / 2018$ academic year is done by making line composition, color circles, drawing according to SBI / SBDP subjects, making jumps, graphic arts (stamp techniques), and exhibition visit. The students have a tendency to feel scared, lack confidence, and are lazy in learning art. Their habits when in class are sleepy, playing cell phones, and sleeping. Even so, 
some students also feel comfortable in practice. Efforts to arouse interest, enthusiasm, and student interest in learning, lecturers provide material by presenting several examples of finished artwork and dividing tasks not only individuals but also groups. To explain how students' art works can be created, it is necessary to observe and aesthetically habitus analysis of students in participating in art learning and skills for learning in elementary schools.

\section{Related Works/Literature Review}

Muslim[4] through the results of a study entitled "Aesthetic Integration in Learning in Primary Schools" explained that aesthetics is an axiological part of science so that the improvement of students' character can be structured in the learning process. Art as a catalyst of aesthetics is integrated in learning, not only in RPP but in the behavior of everyday students. Aesthetic education is included in art learning with the task of training aesthetic sense (beauty) through practice. Aesthetic integration in learning in elementary schools can be done with art integration with other subject matter, namely on the development of learning materials, learning strategies and others. This can be done in the PAIKEM art concept[4].

Sunarto[5] in his article entitled "Aesthetics in the Context of Art Education" explained about aesthetics in building art education for public schools able to provide an objective and representative framework. This is very important as a basis for the personal development of students and the effort to develop the ideals and images of artwork. Learning art is essentially learning the feeling of beauty, beautiful at the time of objectification, beautiful in imagination, and beautiful in expressing it in art, the effects of follow-up. Aesthetic education has a role as character education especially social tolerance. Aesthetic-based art education is still carried out as an art training by simultaneously appreciating artwork[5].

Based on this explanation, the relevance between Muslim[4] research and Sunarto[5] about art learning at the level of school education with the research conducted by the author is the integration of art into everyday life, applying social tolerance of students, and building objectified and representative frameworks. Students have the ability to realize their ideas or ideas from experience and observation. Both of these are embodied in the aesthetic habitus of each student who has his own artistic culture.

\section{Material \& Methodology}

The type of this research used by the qualitative research. Qualitative research is an effort to understand phenomena in their natural setting and context (not in the laboratory), namely the researcher does not attempt to manipulate the observed phenomena[6]. Qualitative research seeks to explore and understand the meaning of the same phenomenon by different people. Although the phenomenon faced is the same, each person will interpret and interpret it differently. "Qualitative research generally leads researchers to focus on aspects that occur in the life of a particular group. Like the physical person, subject or object, mind, emotion feeling, memory, motivation, idea, future views, attitudes, beliefs, opinions, writings, debates, culture, society, groups, and interaction of social relations[7].

The tool used to obtain data is done by interviewing, observing, and reviewing documents. Qualitative data analysis uses semiotics, namely researchers must learn the signs and symbols commonly used in certain domains of science and understand the rules of use. The researcher must unravel the meaning brought by the sign or symbol. Umberto Eco stated that semiotics can be applied in various kinds of research, such as mass communication, visual communication, writing, and others. Semiotics has good potential in analyzing and interpreting data in the form of text, music, photos, videos, and others[6] 
Qualitative data analysis uses semiotics seen from the aspect of objects (visual semiosis), gestures (bodily semiosis), and speech (verbal semiosis). Aspects of objects are analyzed through style of dress, use of objects in advertisements, type of letters, use of symbols, and others. For gesture aspects the writer can observe the facial features, expressive behavior, body posture, body type, face type, body position, and product. While the greeting aspect is obtained from the use of idioms, accents, dialects, metaphors, speech, volume, speed of speech, use of humor, etc[6].

The author chooses aspects of objects and gestures to analyze the aesthetic habitus of the sixth semester students of PGSD in the process of learning art and skills. This is because they practice in the classroom and under the supervision of the lecturer. Types of tasks both independently and in groups are observed and assessed.

\section{Results and Discussion}

In line with Pamadhi, the success of a creation is the success of influencing the masses, namely the recognition of works of art[2]. Art and Skills Education Materials for sixth semester students of PGSD UAD are directed to be able to create beautiful and interesting art works. In addition, learning activities are carried out in accordance with the Semester Learning Plan (RPS) prepared by the lecturer. Every week what activities and competencies must be explained by students.

The process of learning art and skills is carried out in practice by utilizing materials, tools, and media in the surrounding environment. At the first meeting, students were given material, insight and information related to fine arts and skills. The second meeting, they were asked to make a work that was in accordance with the previous introduction. At the second meeting, students are given an assessment indicator used by the lecturer to give value and appreciation for the work that has been made.

There are two types of tasks given, namely individual assignments and group assignments. Individual tasks consist of line composition, color circles, and thematic drawing (according to the selected KI/ KD SBdP class). The composition of the lines is realized in a horizontal, vertical, diagonal, curved, zigzag, spiral, thick, thin, dotted, and cross line arrangement. The composition is made using ballpoints, markers, drawing pens, B-gel, rapido, and black. This task is directed so that students are skilled in making lines and training their fine motor skills. The next step is color recognition and the practice of making colors through color diagrams. Students are given insight into the division or classification of colors namely, primary colors, secondary colors, tertiary colors, complementary colors, and so on. Students are asked to use watercolors, brushes, and pallets to make and arrange colors. The next individual assignment is thematic drawing based on $\mathrm{KI} / \mathrm{KD}$ and the student chooses which class to process. As an example of Class 1 Basic Competency which reads 4.1. Drawing Expressions by Processing Lines, Colors, and Shapes based on Observations in the Surrounding Environment. Students through observation activities combined with empirical experience illustrate in a simple but concrete way in their work. Before practice, students were asked to look for visual and written references related to the assignment given, so that they could add creative thinking in developing ideas.

Group assignments are carried out by group sharing and joint outdoor practices. The work made, namely batik jumping and making observations in the form of art visits to art exhibitions, art museums and cultural venues. Previously they were given each introduction before the practice and preparation of tools, materials, and media. After everything is ready, the students begin to practice in groups with work and individual assessment by the lecturer. 
Students are also asked to be able to make art work or art exhibitions and skills by each class. They compile a work team, make a concept or theme of the exhibition, preparation and implementation of the exhibition. Implementation time for 3 days for each class. In the exhibition, students prepare catalogs, display works, lay out the showrooms, opening events, and supporting activities during the exhibition.

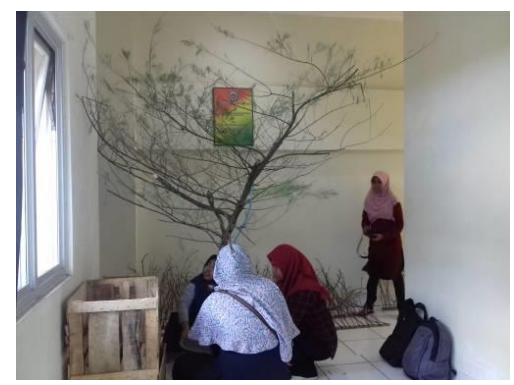

Picture 2. Display Process of Exhibition Work

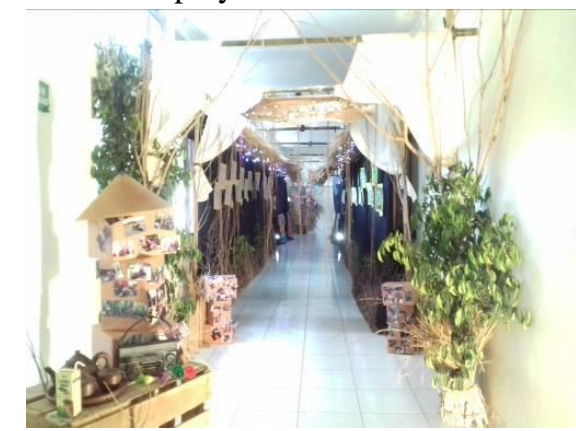

Picture 3. Hallway Building Responding into Exhibition Room

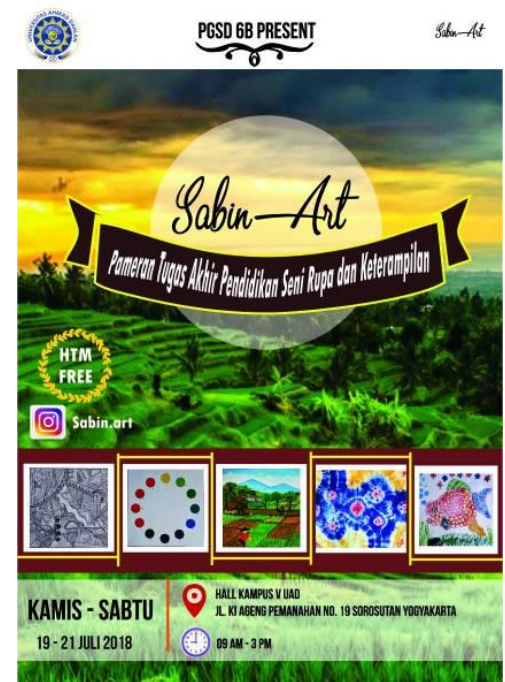

Picture 4. Example of Poster Work Exhibition Advertising 


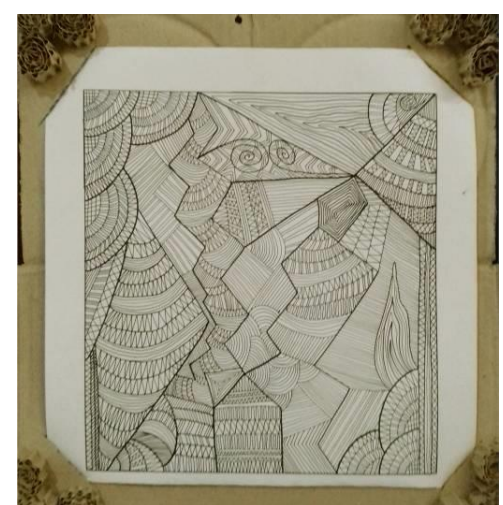

Picture 5. Student Artwork the "Line Composition"

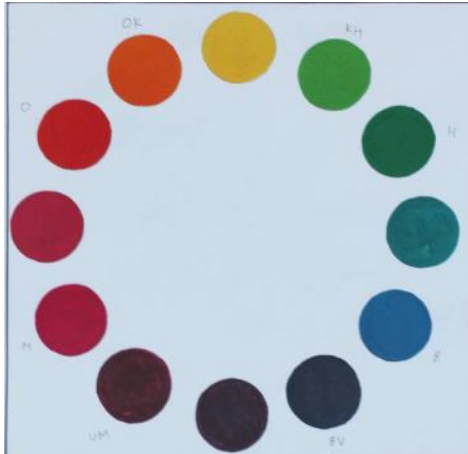

Picture 6. Student Artwork the "Color Circle"

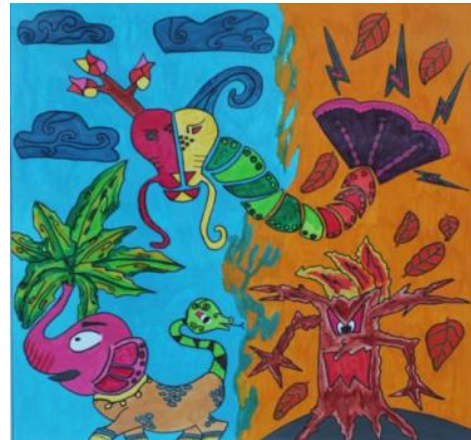

Picture 8. Student Artwork the "Line and Color Exploration" 
Table III. Qualitative Data Analysis with Semiotics

\begin{tabular}{|c|c|c|}
\hline $\begin{array}{l}\text { Object aspect (visual } \\
\text { semiosis) }\end{array}$ & Bodily Semiosis & $\begin{array}{l}\text { Aspects of Speech } \\
\text { (Verbal Semiosis) }\end{array}$ \\
\hline $\begin{array}{l}\text { 1. Students wearing neat and } \\
\text { polite, neat, and Islamic } \\
\text { clothing. } \\
\text { 2. The artworks made based } \\
\text { on material that has been } \\
\text { given in accordance with } \\
\text { KI/ KD and direction from } \\
\text { the lecturer. } \\
\text { 3. Almost everywork } \\
\text { student's uses certain } \\
\text { symbols, for example from } \\
\text { color selection. } \\
\text { 4. Manufacture of exhibition } \\
\text { posters are designed } \\
\text { according to the concept of } \\
\text { each class. Picture } 4 \text { is one } \\
\text { of the posters in class } 6 \mathrm{~B} \\
\text { students entitled "Sabin } \\
\text { Art". } \\
\text { Pictures 5, 6, and } 7 \text { are the } \\
\text { examples of students' } \\
\text { artworks that composes } \\
\text { basic elements and } \\
\text { principles of fine art in the } \\
\text { form of lines, colors, } \\
\text { shapes/ fields, and space } \\
\text { into aesthetic composition. }\end{array}$ & $\begin{array}{l}\text { 1. } \begin{array}{l}\text { Students practice working } \\
\text { in class individually or in } \\
\text { groups. }\end{array} \\
\text { 2. At the initial meeting } \\
\text { students had shown a } \\
\text { nervous, anxious } \\
\text { expression, but can still } \\
\text { smile. } \\
\text { 3. Students had consulted } \\
\text { their artworks in every } \\
\text { practice activities. } \\
\text { 4. Pictures } 2 \text { and } 3 \text { are the } \\
\text { activities of students in } \\
\text { the process of making lay } \\
\text { out of showrooms and } \\
\text { displays all off artworks. }\end{array}$ & $\begin{array}{l}\text { 1. Students used } \\
\text { languange polited } \\
\text { to communicate and } \\
\text { interact when } \\
\text { learning takes place. } \\
\text { 2. The language used } \\
\text { is Indonesian, } \\
\text { because students } \\
\text { come from various } \\
\text { regions. }\end{array}$ \\
\hline
\end{tabular}

\section{Conclusion}

Habitus of art learning and skills is carried out in the sequential stages and steps. Every meeting, the lecturer always gives an introduction, explanations related to the material and steps in the practice of art work, and tips on the work of the exhibition. In addition, students are required to always improve their skills through art work and work consultations during the lectures.

\section{References}

[1] C. D. and S. M. C. 2004. V. and P. A. F. for C. P. Schools, Kindegartern Through Grade Twelve. California: California Department of Education, 2004.

[2] Hajar Pamadhi, Art Education. Yogyakarta: UNY Press, 2012.

[3] M. Grenfell, Pierre Bourdieu: Key Concepts. UK: Acumen Publishing Limited, 2008.

[4] A. Muslim, "Aesthetic Integration in Learning in Primary Schools," J. Model. PGMI Study Progr., vol. 4, 2017. 
[5] Sunarto, "Aesthetics in the Context of Art Education," Educ. Reflect. J. PGSD Study Program. Sunan Muria Kudus Univ., vol. 7, 2017.

[6] S. Sarosa, Qualitative Research Basics. Jakarta: Index, 2017.

[7] S. I. A. Dwininingrum, Educational Research Methods. Yogyakarta: UNY Pess, 2013. 